\title{
La volgarizzazione del disegno tecnico
}

\author{
Pasquale Tunzi
}

Abstract

Un aspetto fondamentale nella comunicazione è il linguaggio, elemento indagato con nuove finalità a partire dagli anni Sessanta del secolo scorso, anche nell'ambito dell'architettura e del disegno. Per quest'ultimo si sono rilevati caratteri propri da cui è emerso un doppio livello di comunicazione: il disegno tecnico e quello illustrativo. In entrambi i casi la comunicazione è stata ritenuta parziale o non del tutto esaustiva. Nello stesso periodo le ricerche nel settore della cibernetica e dell'informatica hanno introdotto nuove prospettive con la formulazione di un linguaggio numerico digitale, gestito in modo veloce dal calcolatore. L'elaborazione del nuovo sistema comunicativo incentrato sul trattamento dell'informazione individuò l'immagine come contenitore di informazioni trasmissibili. II computer rese possibile la visualizzazione grafica, sia bidimensionale che tridimensionale, già in quegli anni, aprendo un nuovo percorso di raffigurazioni. Presto si fronteggiarono la rappresentazione digitale e quella analogica, ma la prima non si è particolarmente distinta nell'uso dei modelli geometrici, e ha mantenuto le due distinzioni del disegno succitate. Noi le abbiamo integrate in un lavoro dedicato alla traduzione di alcuni disegni di progetto, prelevati dall'Archivio di Stato di Pescara, in visualizzazioni 3D. Con queste è stato possibile ridurre il limite di comprensione del disegno tecnico e di recuperare e valorizzare il documento d'archivio.

Parole chiave

disegno tecnico, linguaggio grafico, modello digitale, disegno d'archivio.

Collage di varie forme di rappresentazione elaborate sulla base di (elaborazione di P. Tunzi)

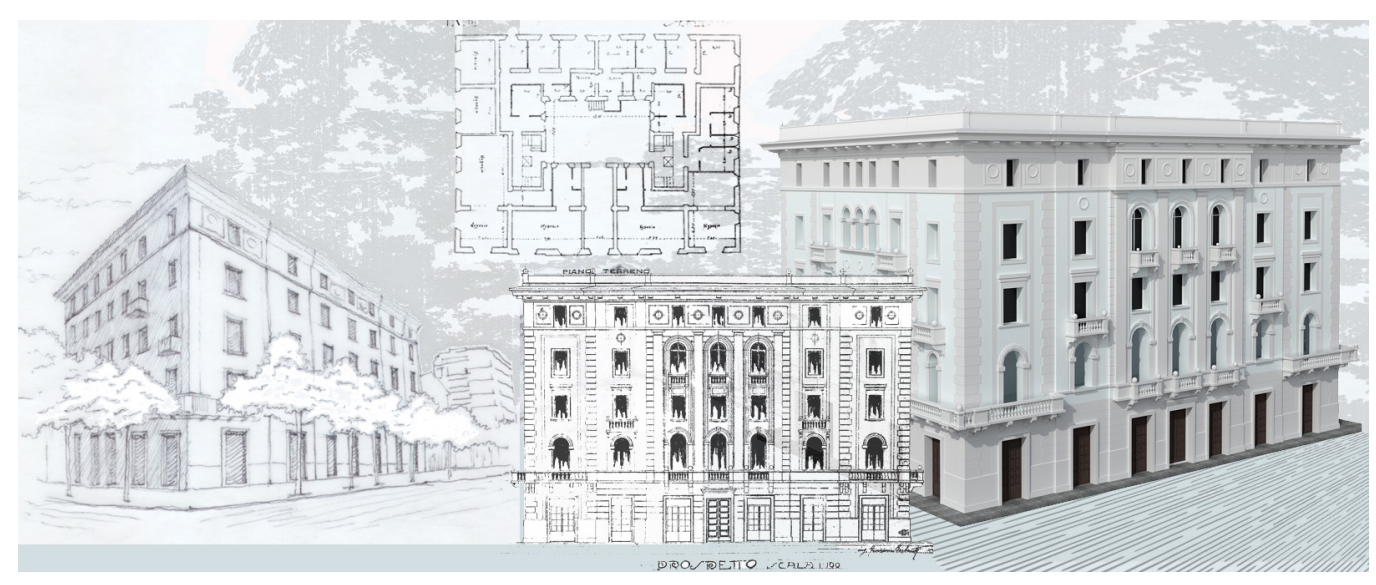

1216 


\section{Introduzione}

"Il disegno architettonico è uno dei molti tipi di disegno che vengono indicati con disegno tecnico, disegno geometrico, disegno professionale, ecc., intendendo significati e aspetti differenti della rappresentazione grafica delle forme reali o immaginarie". Così Gaspare De Fiore introduceva il lungo lemma "Architettonico (Disegno)" inserito nel Dizionario del disegno [De Fiore 1967, p. 188], sintesi di riflessioni sul valore comunicativo della rappresentazione grafica di un ambito che ormai ne annovera molte e qualificate, anche in senso storico. Dall'uso degli aggettivi affiancati alla parola disegno risulta piuttosto evidente l'accezione di programmazione, che rimanda a un metodo di rappresentazione rigoroso e univoco, in cui il fine è determinante.

Sembra esaurirsi in 39l righe il suddetto articolo del dizionario, invece, alcune pagine dopo, viene esplicitata la voce "Architettura (Disegno di)", nella quale De Fiore sottolinea la differenza esistente con la precedente, più fattiva e finalizzata. Quest'ultima è volta a soddisfare la pura visibilità, l'immaginazione anziché la realizzazione, attuata in percorsi figurativi liberamente predisposti dall'autore nell'intento di rendere accessibile la sua idea, il suo pensiero visivo. Al disegno tecnico si affianca, dunque, una forma illustrativa e talvolta suggestiva di raffigurare porzioni di spazio, scorci o dettagli in modo personale.

Allora, si chiede De Fiore, se l'Architettura è l'arte di concepire uno spazio organizzato," "fino a che punto il disegno riesce a «rendere» la spazialità dell'architettura?" [De Fiore 1967, p. 198] La domanda così formulata ci mette di fronte alla potenza dell'articolazione spaziale, e sembra scaturire, più che da una profonda esperienza grafica e da attente osservazioni sul disegno realizzato a mano sul foglio di carta, da qualcosa che in quel momento storico sta avvenendo in un ambito nuovo per la rappresentazione: quello della scienza informatica.

Nel 1966 l'ingegnere meccanico Steven A. Coons, professore al MIT, nel saggio Computer -Aided Design pubblicò l'esito di un lavoro grafico automatizzato, che avrebbe innescato un processo di riflessione e di attualizzazione del disegno tecnico-geometrico. Si tratta di un nuovo modo di trasmettere l'architettura e la sua raffigurazione, evidentemente alternativo ai sistemi tradizionali di tracciamento delle figure. Venne presentato un aspetto del disegno di progetto ignorato sino a quel momento, ossia la ripetizione di alcune operazioni grafiche non creative, e s'introdusse il concetto di dialogo tra uomo e macchina attraverso un linguaggio grafico-computazionale dove il numero sostanzia il segno. L'articolazione di quest'ultimo, riprodotto sul video a conferma dei dati introdotti, era guidata dai consueti modelli geometrici, rispettando per un verso la doppia dimensione e per l'altro la tridimensionalità, ma soprattutto rivelò un sistema di controllo grafico determinato da algoritmi. In tal modo la geometria descrittiva e quella analitica trovarono un punto d'incontro nello schermo del calcolatore, e dal lungo percorso che ne è seguito, disseminato di importanti tracce, sembra pervenire una risposta, seppur non del tutto esaustiva, alla domanda posta da De Fiore.

Oggi però, a distanza di oltre cinquant'anni dalle prime esperienze di grafica assistita, tale domanda torna ad essere attuale e merita una riflessione.

\section{II limite del disegno tradizionale}

Per molto tempo - tenendo presente in particolare gli anni '60 - si è parlato diffusamente di linguaggio grafico, come sistema universale di comunicazione, insieme a una serie di attributi. L'opportuna attenzione rivolta al linguaggio, in senso lato, scaturì da quanto diffondeva la cibernetica, neonata scienza nella quale uomo e macchina si trovarono uniti nel controllo della comunicazione. Fu un aspetto decisamente interessante fondato sull'informazione, a cui si legava la trasmissibilità, l'interpretazione e la traduzione sul piano semantico del linguaggio [Wiener 1966].

Gli sviluppi di questo argomento generarono nei più vari ambiti della cultura, ampie e profonde riflessioni sulle diverse espressioni linguistiche, tra le quali si annoverano numerosi contributi a riguardo dell'Architettura e del Disegno. Tra questi è da ricordare quanto scrisse 
Luigi Vagnetti [1965] in merito al disegno architettonico, spinto dall'esigenza di precisarne il significato e di chiarirne le diverse declinazioni, ritenute all'epoca alquanto confuse. Nel testo emerge anzitutto la mera funzione strumentale del disegno finalizzata al "fare architettura", ossia al costruire, e viene sottolineata una certa affinità tra le due discipline. La lettura ci conduce per un verso ad assumere il disegno come atto prescrittivo, caratterizzato da codici e precise regole; per l'altro a ritenere che la forza espressiva del disegno e la capacità di essere recepita chiaramente e con immediatezza da chiunque, sia prerogativa dell'ideatore.Vagnetti, dunque, intende rimarcare due facce distinte di una stessa medaglia, due forme comunicative differenti per un fine che potrebbe non essere comune ad entrambi.

Questa bipartizione assunta da De Fiore, con diverse sfumature, la ritroviamo anche in Cesare Brandi (1966) quando, traslando il discorso, affronta la lettura dell'opera d'arte, già annunciata in Segno e immagine [1960]. II naturale intreccio delle due forme grafiche comunicative, differenti e tuttavia complementari, tende a dotare l'oggetto rappresentato di un valore aggiunto sul piano della trasmissibilità e della sua comprensione, peraltro unico rispetto ad altri ambiti al di fuori dell'architettura.

In tutti i casi il discorso è da ricondursi alla percezione dell'oggetto rappresentato, "al prelevamento" di particolari che ne fanno la conoscenza. Quella forma espressiva del disegno di progetto, attinente alla mimesi dello spazio, possiamo dunque intenderla come un atto di volgarizzazione dell'idea progettuale. La diretta comunicazione delle forme espletata attraverso prospettive e assonometrie, permette di cogliere meglio il senso delle idee rispetto al disegno tecnico. Tuttavia questi due modelli geometrici non fanno che mostrare alcuni aspetti del soggetto e ne nascondono altri [Merleau-Ponty 1967], rivelando così il proprio limite comunicativo. Ė quanto accade anche del disegno tecnico, in cui la vera immagine del soggetto è presentata a frammenti o per parti. Si ha una riduzione della spazialità in due dimensioni che fa perdere la completezza del soggetto [Ugo 2002].

Sul piano, quindi, della compiutezza della rappresentazione, in cui architettura e disegno convivono, invero sin dall'antichità, come Vagnetti ha sottolineato, negli ultimi due decenni del Novecento ha affrontato un passaggio importante, interessando l'elaborazione digitale. Lo sviluppo e l'impiego di appositi software per la visualizzazione del progetto, avulso da norme e da codici specifici, si rivolge all'aspetto del soggetto affermandone la realtà oggettiva: questo significa favorire la percezione visiva. II calcolatore ha quindi favorito sullo schermo una rappresentazione e una fruizione più dinamica del soggetto rappresentato, soprattutto quando quest'ultimo assume una tridimensionalità spaziale facilmente gestibile sul piano visuale.

\section{Reinventare la comunicazione del disegno di progetto}

II disegno tecnico, con le sue proprietà trasmissive e commutative, è sempre stato, come tutti sanno, il trait d'union tra progettisti ed esecutori. Diversamente da altre forme di rappresentazione grafica, il suo carattere rigorosamente geometrico e di natura funzionale, che in campo architettonico coinvolge l'idea creativa di spazi inventati, lo assimila a uno schema produttivo. Dopo la stesura entra nel tempo e nel luogo della esecuzione del manufatto, e dalle mani del progettista passa naturalmente in quelle degli operai. Compiuta l'opera il disegno di progetto sembra aver esaurito il suo compito e viene quindi abbandonato o distrutto.

Com'è ben noto, ciò che distingue il disegno tecnico dalle altre raffigurazioni di settore è l'assunzione del numero col quale si governa il processo di razionalizzazione, legandosi al concetto di scala. L'adozione della misura rispetto all'impiego di rapporti proporzionali e intuitivi, lo rende sempre pronto all'esecuzione pratica, al di là del tempo in cui è stato prodotto. Questo dato è fondamentale per poter avviare un'operazione di revisione formale di quanto è in esso contenuto, prescindendo dal valore del soggetto rappresentato e dal fatto se vi è stata o meno fisica realizzazione.

I disegni di progetto rimasti sulla carta, ossia quelle indicazioni che non sono state impiegate per la costruzione e che fortunatamente ritroviamo in un deposito o in un archivio, meri- 
tano uguale attenzione. Anzi, sono proprio questi disegni in attesa di una esecuzione che mai avverrà, a dover essere presi in considerazione per apprezzarne la qualità e molti altri aspetti. Su di essi possiamo eseguire studi di vario genere, ma soprattutto è possibile dar loro una visibilità diversa, decisamente più immediata e diretta, attraverso la traduzione in altro genere di immagine. Utilizzando il dato mensorio eseguiamo, ad esempio, modelli digitali, ossia elaborazioni virtuali che ne riscattino la loro "sospensione" e li recuperino dall'oblio, nel rispetto dei caratteri propri del soggetto. Attraverso la nuova visibilità particolarmente descrittiva si concede un'altra vita allidea progettuale e si aprono percorsi di indagine da esperire.

È quanto abbiamo fatto su una serie di progetti dei primi anni del Novecento rinvenuti presso l'Archivio di Stato di Pescara. Nell'intraprendere la traduzione digitale di alcuni di questi disegni originali, dopo averli osservati attentamente e analizzati, è stato necessario stabilire cosa di essi costituisca informazioni significative, da trasferire nella forma virtuale. L'operazione, alquanto delicata, è stata svolta, in accordo con il suddetto archivio, per sostenere la memoria di interventi compiuti sulla città. Ne è emersa una città parallela, forse ideale, e tuttavia invisibile ma esistente nelle polverose carte. La finalità dell'intero lavoro era quella di mostrare a un vasto pubblico i caratteri di architetture proposte dai progettisti locali, sostenitori di una certa idea di città nella prima metà del Novecento. Un modo, questo, per visualizzare le occasioni mancate da cui si è levata la città attuale (fig. I),

II rimaneggiamento dei disegni d'archivio, per un verso consente di reimmergersi nell'universo possibile della fabbricazione storica, di rintracciare alcuni itinerari del progettista, e di scoprire cosa c'è dietro il disegno. Per l'altro è fornire una chiave di lettura alternativa con la quale evitare di affrontare gli aspetti specificamente tecnici. In altre parole, questo genere di visualizzazione spaziale contribuisce a volgarizzare il disegno di progetto, così poco accessibile alla comprensione "popolare".

Il linguaggio computazionale, ormai piuttosto evoluto, sappiamo bene quanto possa offrire rispetto al linguaggio grafico tradizionale, cosi fisso, sempre uguale, limitato e poco esaustivo nel comunicare la spazialità dell'architettura, come ha rilevato De Fiore. L'aspetto "tridimensionale" da qualche tempo si pone in modo preponderante nella visualizzazione di un oggetto ideato, divenendo il riferimento per il disegno tecnico. Ė tanto forte questa propensione da aver sovvertito il consueto iter di stesura del progetto, che ancora per poco avrà elaborati bidimensionali in formato cartaceo.

\section{Conclusione}

Il linguaggio grafico e visuale, come ogni altra forma comunicativa, pone delle regole e quindi delle limitazioni, entro le quali si costruisce un prodotto. Certamente "ogni linguaggio ha il suo 'universo di segni', il suo 'codice' particolare" [Koenig 1970, p. 18] che in architettura ritroviamo soltanto nel disegno tecnico supportato dalle cognizioni di geometria proiettiva. Ad un tempo il disegno rivela e nasconde alcuni aspetti del soggetto progettato, che la rappresentazione digitale può mostrare in modo decisamente diverso e probabilmente più esaustivo, riducendo di molto quanto non sia visibile. Nel presentare a video un'apparente tridimensionalità, perlustrabile, osservabile in pochi istanti da più punti di vista, e misurabile, è certamente il vantaggio supportato dalla dotazione di informazioni e di dati significativi contenuti in ogni suo punto, linea e superficie.

II rapporto stretto tra visibile e narrazione, e tra somiglianza e modalità d'azione, è costruito dall'operazione di visualizzazione [Gaiani 1997]. L'elaborazione digitale non vuole porsi come patrimonio rappresentativo nuovo o alternativo, bensì, nella sua capacità di indagare 0 soltanto di illustrare, intende accostarsi alle forme del passato, senza prevaricarle o escluderle. Certamente rivela un proprio senso estetico, dovuto al mezzo della rappresentazione, ma questo non preclude altre forme grafico-visuali di indagine, anzi le favorisce e con esse si integra.

Se la proiezione ortogonale può essere ritenuta una limitazione alla fisionomia dell'oggetto, bisogna far attenzione al modello 3D che non lo sia ancor più, in quanto nella traduzio- 

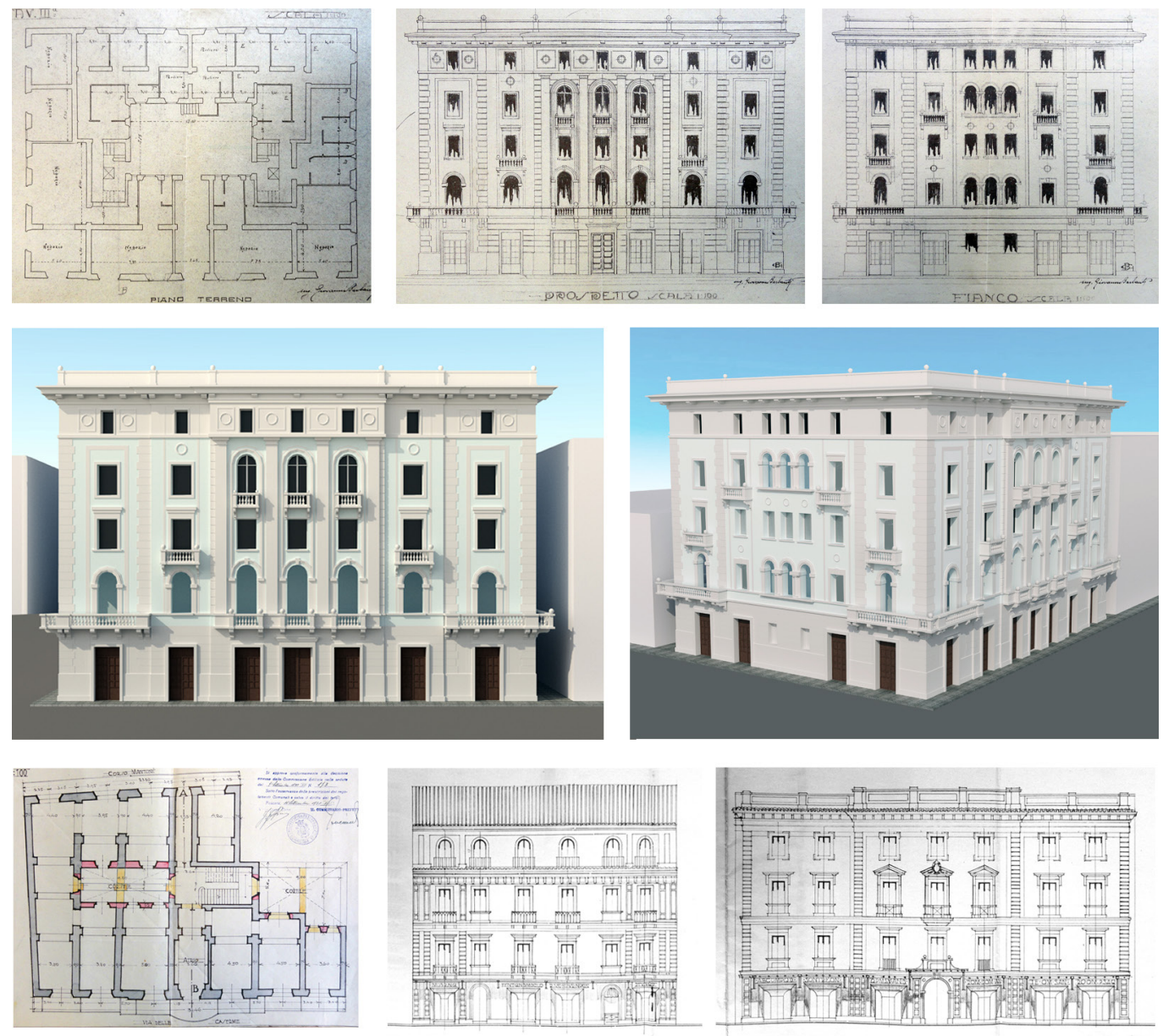

Fig. I. Alcuni documenti d'archivio di due palazzi storici di Pescara non realizzati e rielaborati in 3D.
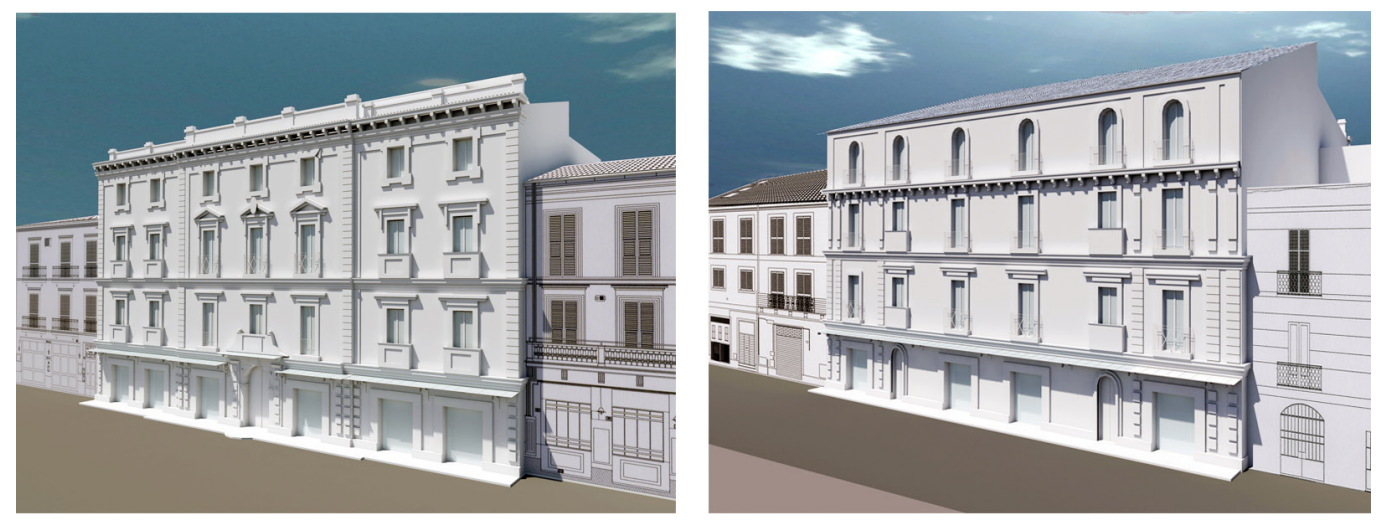
ne di un documento grafico il margine di interpretazione è molto labile e l'esito finale è difficilmente travisabile. Tuttavia nell'assenza del codice tecnico, col 3D il soggetto si rende leggibile, per restituire una percezione inedita, uno sguardo rinnovato su prodotti cartacei che la cultura condivisa tende a considerare obsoleti, ormai inutili. E non va trascurato che questa forma di recupero, in una comunicazione così immediata ed esaustiva, ha una particolare presa sul fruitore comune. Ciò permette a molta ricerca e produzione scientifica di venir divulgata e assunta dai vari strati della società.

Riteniamo, dunque, che nella trasposizione dal disegno analogico alla rappresentazione digitale 3D vi è il passaggio dalla potenza all'atto, un movimento di informazioni dunque che consente di realizzare la forma, seppur soltanto visuale, ma che prelude alla fisicità della costruzione se trattata con un'adeguata renderizzazione [Alexander 2020].

Trasferire il disegno dallo stato analogico al digitale, come si può intuire, offre una conoscenza trasversale necessaria alla trasmissione del sapere, e nei riguardi del documento ne estende la ragione di vita. Più precisamente, lo ribadiamo, si tratta di traduzione del disegno, da un linguaggio tradizionale, a carattere grafico, a un linguaggio numerico, a carattere visuale. Quest'ultimo, tuttavia, pur palesando la fiducia nell'uso dell'algoritmo, rivela l'intenzione conservatrice delle tradizionali forme di rappresentazione, tardando ancora a emanciparsi da esse.

\section{Riferimenti bibliografici}

Alexander Z., May J. (Eds.). (2020). Design Technics: Archaeologies of Architectural Practice. Minneapolis; London: University of Minnesota Press.

Brandi C. (1966). Le due vie. Bari: Laterza.

Coons S. A. (1966). Computer-Aided Design. In Design Quarterly, n. 66/67, pp.6-I3.

De Fiore G. (1967). Dizionario del disegno. Brescia: La scuola editrice.

Gaiani M. (1997). Trasmutazioni dal pensiero al reale: costruzione, ovvero rappresentazione della finzione. In M. Docci, M. Cigola, T. Fiorucci (a cura di). Atti del Convegno II disegno di progetto: dalle origini al XVIII secolo. Roma 22-24 aprile I993, p. 449. Roma: Gangemi editore.

Koenig G. K. (1970). Architettura e comunicazione. Firenze: Libreria Editrice Fiorentina.

Merleau-Ponty M. (1967). Segni. Milano: II Saggiatore.

Ugo V. (2002). Fondamenti della rappresentazione architettonica. Bologna: Progetto Leonardo.

Vagnetti L. (1965). Il linguaggio grafico dell'architetto, oggi. Genova:Vitali e Ghianda.

Wiener N. (1966). Introduzione alla cibernetica. Torino: Bollati Boringhieri.

Autore

Pasquale Tunzi, Università degli Studi “G. d'Annunzio” Chieti-Pescara, tunzi@unich.it

Per citare questo capitolo:Tunzi Pasquale (2021). La volgarizzazione del disegno tecnico/The vulgarisation of technical drawing. In Arena A., Arena M., Mediati D., Raffa P. (a cura di). Connettere. Un disegno per annodare e tessere. Linguaggi Distanze Tecnologie. Atti del $42^{\circ}$ Convegno Internazionale dei Docenti delle Discipline della Rappresentazione/Connecting. Drawing for weaving relationship. Languages Distances Technologies. Proceedings of the $42^{\text {th }}$ International Conference of Representation Disciplines Teachers. Milano: FrancoAngeli, pp. $1216-1227$. 


\title{
The Vulgarisation of Technical Drawing
}

\author{
Pasquale Tunzi
}

Abstract

Language is a fundamental aspect of communication. Beginning in the 1960s, it was investigated with new objectives, also in the field of architecture and design. The specific characteristics of these disciplines revealed two levels of communication: technical drawing and illustration. In both cases, their communication was considered partial and incomplete. During the same period, research in the field of cybernetics and information technologies introduced new perspectives through the formulation of a digital language of numbers managed rapidly by the computer. In the development of this new system of communication based on data processing the image was identified as the container of transmissible information. The computer, already capable during this period of both two and three-dimensional graphic visualisations, set a new path for representation. This was immediately followed by a comparison between digital and analog representation; however, as the former was not particularly suited to geometric models, the two distinctions between the aforementioned drawings remained. These two distinctions were recently integrated in a project to translate digitalise a selection of architectural drawings conserved at the State Archives in Pescara into 3D visualisations. The results served to heighten the comprehensibility of technical drawing and rediscover and restore value to the original documents.

Keywords

technical drawing, graphic language, digital model, archival drawings.

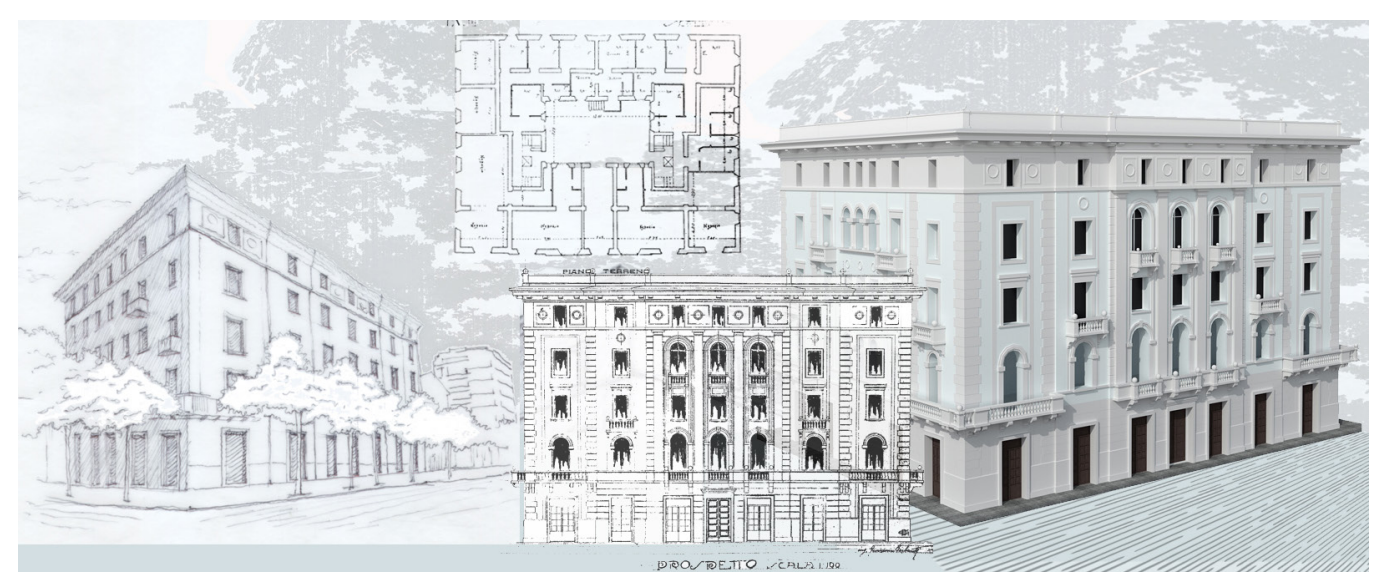




\section{Introduction}

"The architectural drawing is one of many types of drawings known as technical drawings, geometric drawings, professional drawings, etc., which refer to different meanings and aspects of the graphic representation of real or imaginary forms". This is how Gaspare De Fiore introduced the lengthy definition "Architectural (Drawing)" in the Dizionario del disegno [De Fiore 1967, p. 188], a synthesis of reflections on the communicative value of graphic representation in a field that now includes many and variously qualified forms, also historical.The coupling of adjectives with the word drawing clearly emphasises a programmatic aspect referred to a rigorous and univocal method of representation, with a specific objective.

While this dictionary definition would appear to cover all the bases in its 39I words, a few pages further on we find the definition "Architecture (Drawing of)". In it De Fiore outlines the difference with respect to the previous definition, more effective and targeted. This second definition privileges pure visibility and imagination over realisation. It takes the form of figurative approaches freely arranged by their author whose intention it to make an idea accessible, to visually represent a vision. So, technical drawing is also accompanied by more personal illustrative and often suggestive approach to the depiction of spaces, views or details.

Thus, De Fiore asks, if Architecture is the art of conceiving of organised space, "to what point does drawing manage to 'render' the spatial qualities of architecture?" [De Fiore 1967, p. 198].

Posed in this manner, the question presents us with the power of spatial articulation and appears to be triggered, more than by a profound graphic experience and attentive observation of drawings made by hand on paper, by something that occurred at a specific moment in history in a new field of representation: computer science.

In 1966, the mechanical engineer and professor at MIT Steven A. Coons published the essay Computer-Aided Design, presenting the results of an automated graphic project that would trigger a reflection and move toward the actualisation of technical-geometric drawing. Coons' work introduced a new way of communicating and representing architecture that was an evident alternative to traditional systems of figural drawing. An aspect of drawing architecture ignored until this moment now presented itself: the repetition of non-creative graphic operations. At the same time, it also introduced the concept of dialogue between man and machine through a graphic-computational language that used numbers to substantiate signs. The articulation of this language, whose reproduction on a video terminal confirms the original input data, was guided by known geometric models, in both two and three dimensions; above all it revealed a system in which graphics are controlled by algorithms. Descriptive and analytical geometry thus came together on the computer screen. The lengthy development that followed, disseminated with important suggestions, appears to arrive at an answer, albeit not entirely exhaustive, to De Fiore's question.

However, more than fifty years after the first experiences with assisted graphics, this question is once again topical and worthy of consideration.

\section{The Limit of Traditional Drawing}

For many years -in particular during the 1960s- there was widespread discussion of graphic language as a universal system of communication, accompanied by a series of attributes. This opportune interest in language, in the broadest sense, was triggered by the new-born science of cybernetics in which man and machine were united by the control of communication. This was a truly interesting aspect founded on information, linked to the transmissibility, interpretation and semantic translation of language [Wiener 1966].

The developments of this question generated broad and profound reflections on diverse expressions of language in the most varied fields of culture, including numerous contributions to Architecture and Design. Among them, it is worth remembering what Luigi Vagnetti 
[1965] wrote about architectural drawing, driven by the need to precisely describe its significance and clarify its diverse definitions, at the time considered rather confused. What emerges above all from this text is the purely instrumental function of drawing for "creating architecture", in other words, for building. The text also emphasises a certain affinity between the two disciplines. This reading leads us on the one hand toward a consideration of drawing as a prescriptive act, characterised by codes and precise rules; on the other hand it suggests that the expressive strength of drawing, and its ability to be clearly and immediately understood by anyone, is a prerogative of its creator. Vagnetti therefore wished to emphasise two distinct sides of the same coin, two different forms of communication for a purpose that may not be common to both.

We find the bipartition assumed by De Fiore, with diverse facets, also in Cesare Brandi's (1966) translation of this discourse to the reading of the work of art, previously announced in Segno e immagine [1960]. The natural intersection between these two forms of graphic communication, different yet complementary, tends to provide the object represented with an added value in terms of its transmissibility and comprehension that, what is more, is unique with respect to other fields outside architecture.

In all cases, the discourse must be traced back to the perception of the object represented, "to the borrowing" of details that make it recognisable. Hence, this expressive form of architectural drawing, related to the mimesis of space, can be considered a vulgarisation of the original design idea. The direct communication of forms in perspectives and axonometrics permits a better comprehension of the meaning of ideas with respect to technical drawing. Nevertheless, both geometric models represent only some aspects of the subject and conceal others [Merleau-Ponty 1967]. In so doing, they reveal their limit in communicating the original idea. The same can be said of technical drawing, which represent the true image of the subject in fragments or parts. Space is reduced to two dimensions, and the completeness of the subject is lost [Ugo 2002].

Thus, the completeness of representation, where architecture and drawing coexist since antiquity, as Vagnetti points out, took an important step during the final two decades of the twentieth century with the arrival of digital drawing. The development and use of special software for visualising architecture, unhindered by specific norms and codes, affirms the objective reality of what is represented: this signifies favouring visual perception. The computer screen has thus favoured a more dynamic representation and fruition of what is represented, above all when it can be easily visualised in three dimensions.

\section{Reinventing the Communication of Architectural Drawing}

As we know, thanks to its transmissive and commutative properties, the technical drawing has forever been the trait d'union between designers and builders. Diverse from other forms of graphic representation, its rigorously geometric character and functional nature, that begins in the field of architecture with a creative idea that invents spaces, makes it similar to a production diagram. Once complete, it enters into the time and place of construction, naturally passing from the hands of the designer into those of the builder. When the object is complete, the architectural drawing has exhausted its role and is either abandoned or destroyed.

It is well known that what distinguishes technical drawing from other specialised representations is the use of numbers to govern the process of rationalisation, linked to the concept of scale. The adoption of a scale in lieu of proportional and intuitive ratios ensures the drawing is always ready for practical use, even long after it was first produced. This aspect is fundamental to any operation that involves a formal revision of its content, regardless of the value of the subject represented and whether or not it was physically realised.

Drawings of projects that remain on paper, in other words, indications that were never used to build anything and that, fortunately, can be found in storage or in an archive, merit equal attention. In reality, precisely these drawings awaiting an act of building that will never occur, must be considered in order to appreciate their qualities, as well as many other 
aspects. They can be the object of various studies. Above all, we can provide them with a different form of visibility, decidedly more immediate and direct, by translating them into another type of image. We can use their measurements, for example, to create digital models: virtual elaborations that revendicate their "suspension" and recover them from oblivion by showing respect for the specific characteristics of what they represent. This new highly descriptive visibility grants another life to the original idea and opens the door to future investigations.

This is what we have done with a series of projects from the early twentieth century, conserved in the State Archives in Pescara. This digital translation of a selection of original drawings began with a phase of attentive observation and analysis. Among the information they contain, it was necessary to decide what was important enough to be transferred into their virtual representation. This rather delicate operation was carried out together with staff from the Archive to support the memory of projects created for the city. What emerged was a parallel and perhaps ideal city, invisible yet existing in these dusty documents. The objective of this project was to present the general public with the characteristics of architectural projects developed by local designers who championed a particular idea of the city during early twentieth century. It is a means for visualising missed opportunities for the city (fig. I).

The redrafting of these archival drawings, on the one hand permits us to re-immerse ourselves in a possible universe of historical buildings, to retrace the itineraries of their authors, and to discover what lies behind the drawing. On the other hand, it produces an alternative interpretation that avoids specifically technical questions: this from of spatial visualisation helps vulgarise the specific language of architectural drawing, largely incomprehensible to the 'general' public.

We are well aware what the language of the computer - now highly evolved - is capable of offering with respect to a traditional graphic language that is fixed, always the same, limited and incomplete in its communication of the spatial qualities of architecture, as De Fiore noted. For some time now, "three-dimensional" visualisation has gained the upper hand in the representation of architecture; it has also become a reference for technical drawing. This tendency is so strong that it has subverted the how a project is developed; there is little doubt that two-dimensional paper drawings are destined to disappear.

\section{Conclusions}

A graphic and visual language, like any other form of communication, imposes rules and limitations, which we employ to develop a product. Certainly, "each language has its own 'universe of signs', its own particular 'code'" [Koenig 1970, p. I8]. In Architecture we find them only in the technical drawing supported by the cognitions of projective geometry.

While drawing simultaneously reveals and conceals aspects of the subject represented, digital representation offers a decisively different and possibly more exhaustive representation by significantly reducing what is not visible. The ability to present an apparent three-dimensionality on a video terminal, explorable and observable rapidly and from different points of view, as well as being measurable, is certainly an advantage, what is more supported by the vast amount of information and important data contained in each of its points, lines and surfaces.

The close relationship between the visible and the narrative, and between resemblance and method of action, is founded atop an operation of visualisation [Gaiani 1997]. Digital drawing is not intended as a new or alternative body of representations; instead, for its capacity to investigate or merely illustrate, it should be placed alongside the forms used in the past, neither dominating nor excluding them. Though it certainly has its own aesthetic, resulting from its means of representation, rather than precluding other graphic-visual forms of investigation, it favours and integrates them.

While orthogonal projection can be considered a limit on the physiognomy of the object, we must take care to ensure that the 3D model does not worsen this situation. The digi- 

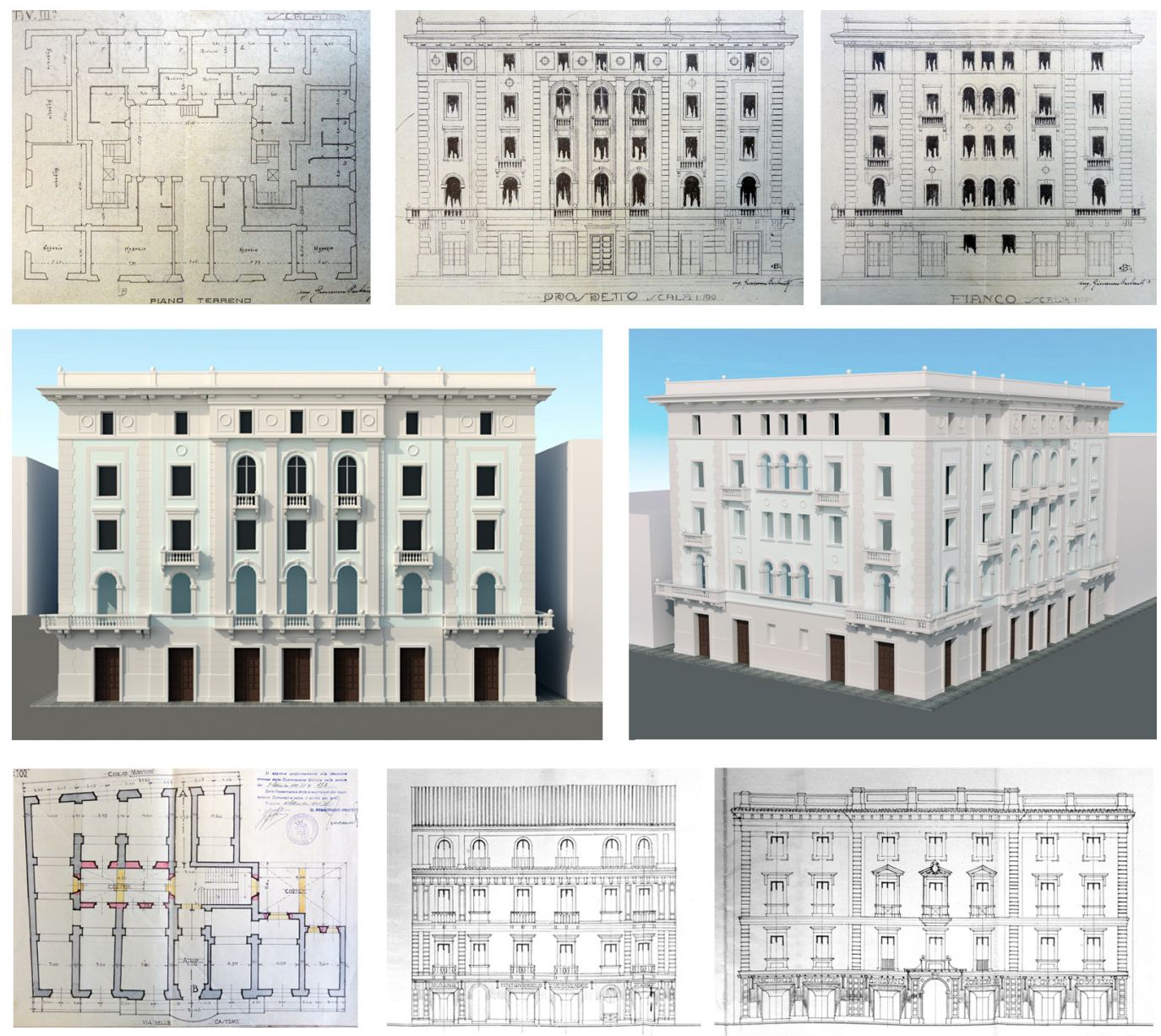

Fig. I. Some archival documents of two historic buildings in Pescara not built and reworked in 3D.

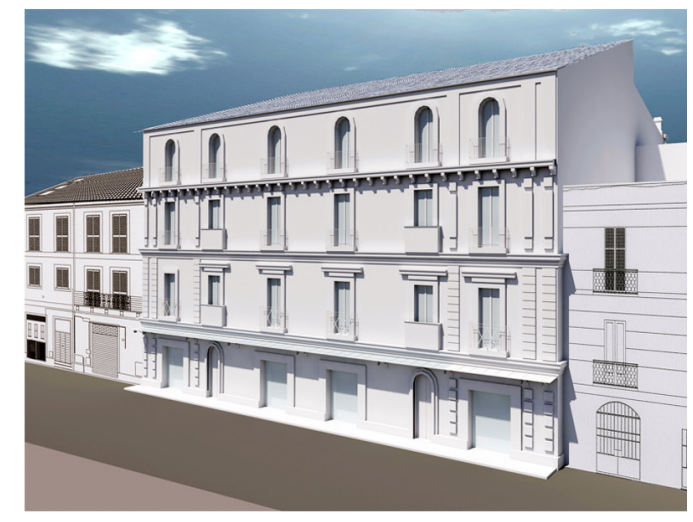


talisation of a graphic drawing leaves ample margins for interpretation and the final result is easily mispresented. However, stripped of its technical code, the 3D representation of the subject is more legible; it restores an entirely new perception, a new way of looking at the paper products that contemporary culture tends to consider obsolete, and useless. Neither can we ignore that this form of recovery, by using such an immediate and exhaustive form of communication, has a particular impact on the general observer. Such an immediacy permits a great deal of scientific research and results to be disseminated and comprehended at various levels of society.

We thus consider that the translation of analog drawings into 3D digital representations contains a passage from potential to action, a movement of information that permits the realisation of form, even in a purely visual state, but capable of suggesting the physical nature of construction when adequately rendered [Alexander 2020].

The digitalisation of analog drawings, as we can see, permits a transversal comprehension that facilitates the transmission of knowledge and exceeds the raison d'être of the original document. More precisely, it must be noted, this process translates a drawing from a traditional and graphic language into a visual language of numbers. Despite placing its trust in the algorithm, the process conserves traditional forms of representation and further delays the emancipation from them.

\section{References}

Alexander Z., May J. (Eds.). (2020). Design Technics: Archaeologies of Architectural Practice. Minneapolis; London: University of Minnesota Press.

Brandi C. (1966). Le due vie. Bari: Laterza.

Coons S. A. (1966). Computer-Aided Design. In Design Quarterly, n. 66/67, pp.6-I3.

De Fiore G. (1967). Dizionario del disegno. Brescia: La scuola editrice.

Gaiani M. (1997). Trasmutazioni dal pensiero al reale: costruzione, ovvero rappresentazione della finzione. In M. Docci, M. Cigola, T. Fiorucci (a cura di). Atti del Convegno II disegno di progetto: dalle origini al XVIII secolo. Roma 22-24 aprile I993, p. 449. Roma: Gangemi editore.

Koenig G. K. (1970). Architettura e comunicazione. Firenze: Libreria Editrice Fiorentina.

Merleau-Ponty M. (1967). Segni. Milano: Il Saggiatore.

Ugo V. (2002). Fondamenti della rappresentazione architettonica. Bologna: Progetto Leonardo.

Vagnetti L. (1965). Il linguaggio grafico dell'architetto, oggi. Genova:Vitali e Ghianda.

Wiener N. (1966). Introduzione alla cibernetica. Torino: Bollati Boringhieri.

\section{Author}

Pasquale Tunzi, Università degli Studi “G. d'Annunzio” Chieti-Pescara, tunzi@unich.it

To cite this chapter. Tunzi Pasquale (2021). La volgarizzazione del disegno tecnico/The vulgarisation of technical drawing. In Arena A., Arena M. Mediati D., Raffa P. (a cura di). Connettere. Un disegno per annodare e tessere. Linguaggi Distanze Tecnologie. Atti del $42^{\circ}$ Convegno Internazionale dei Docenti delle Discipline della Rappresentazione/Connecting. Drawing for weaving relationship. Languages Distances Technologies. Proceedings of the $42^{\text {th }}$ International Conference of Representation Disciplines Teachers. Milano: FrancoAngeli, pp. $1216-1227$ 